\title{
Exergy flow of rice production system in Italy: Comparison among nine different varieties
}

\author{
Amin Nikkhah a,b, Armaghan Kosari-Moghaddam ${ }^{c}$, Mahdi Esmaeilpour Troujeni ${ }^{\mathrm{c}}$, Jacopo \\ Bacenetti $^{\text {d,* }}$, Sam Van Haute ${ }^{\text {a,b }}$ \\ ${ }^{a}$ Department of Food Technology, Safety and Health, Faculty of Bioscience Engineering, Ghent University, \\ Coupure Links 653, 9000 Ghent, Belgium \\ ${ }^{\mathrm{b}}$ Department of Environmental Technology, Food Technology and Molecular Biotechnology, Ghent Univers \\ ity Global Campus, Incheon, South Korea \\ ${ }^{\mathrm{c}}$ Department of Biosystems Engineering, Ferdowsi University of Mashhad, Mashhad, Iran \\ ${ }^{\mathrm{d}}$ Department of Environmental Science and Policy, Università degli Studi di Milano, Via G. Celoria 2, \\ 20133 Milan, Italy
}

\begin{abstract}
Exergy analysis is receiving considerable attention as an approach to be applied for making decisions toward moving to a sustainable and energy-efficient food supply chain. This study focuses on how the selection of variety affects the exergy flow of a paddy rice production system. In this regard, nine varieties of rice in Italy, the largest rice producer in Europe, were evaluated using the cumulative exergy analysis approach. Sensitivity analysis of inputs consumption and the exergy management scenarios of the most sensitive inputs are also provided in this study. The results indicated that the cumulative exergy consumption value of the investigated rice varieties ranges from 16.09 $\mathrm{GJha}^{-1}$ to $25.80 \mathrm{GJ} \mathrm{ha}^{-1}$. Fossil fuels and chemical fertilizer consumption were the most significant contributors to the total energy consumption in all investigated varieties. Luna variety, with the cumulative degree of perfection value of 7.96 and renewability indicator of 0.88 , was identified as the most exergy-efficient variety of rice in Italy.
\end{abstract}

Keywords: Crop production, Cumulative degree, Energy, Renewability indicator 


\section{Nomenclature}

\begin{tabular}{|llll|}
\hline Acronyms & & & \\
$\mathrm{CDP}$ & cumulative degree of perfection & $\mathrm{H}-\mathrm{GLG}$ & high-grade long-grain \\
$\mathrm{CExC}$ & cumulative exergy consumption & $\mathrm{H}-\mathrm{YLG}$ & high-yielding long-grain \\
$\mathrm{CH}_{4}$ & methane & $\mathrm{MJ}$ & mega joule \\
$\mathrm{CO}_{2}$ & carbon dioxide & $\mathrm{N}$ & nitrogen \\
$\mathrm{GHG}$ & greenhouse gas & $\mathrm{P}_{2} \mathrm{O}_{5}$ & phosphate \\
$\mathrm{GJ}$ & gigajoule & $\mathrm{K}_{2} \mathrm{O}$ & potassium \\
ha & hectare & $\mathrm{RI}$ & renewability indicator \\
\hline
\end{tabular}

\section{Introduction}

Rice has shaped the diet, economics, and culture of millions of people worldwide (Amanullah and Fahad, 2017). It is considered the third most produced crop after maize and wheat on the planet (Mauryaet al., 2017), and it is the most important food crop in Asia (Clauss et al., 2017). Rice is also a multifunctional crop, which can be used as food, feed, and feedstock for bioenergy production (Phitsuwan and Ratanakhanokchai, 2014). Italy is the main rice producer in Europe with an area of 234,133 ha and the amount of rice production of over 1.5 million tons (Graziano et al., 2020). China is the largest rice producer and consumer in the world with an area of 30 million hectares with a total amount of 145 million tons (Yang et al., 2018).

Rice production faces several environmental issues, such as huge carbon (Shang et al., 2011; Bacenetti et al., 2017), and water (Chapagain and Hoekstra, 2011) footprints, and the impact of pesticides consumption for rice production on human health (Pingali et al., 2012). One of the adverse environmental challenges of rice production is the direct methane $\left(\mathrm{CH}_{4}\right)$ emissions from rice fields; methane emission from rice farms is known as one of the dominant contributors to anthropogenic global warming (Eusufzai et al., 2010). Methane emissions from rice farms are affected by the farming systems (irrigated, rainfed), fertilizer, organic input (Fusi et al., 2014) and rice varieties (Zhang et al., 2016).

Several studies indicate that the selection of rice variety can also affect the sustainability indices of the production system. For instance, Taheri-Rad et al. (2017) studied the energy flows of high-grade long-grain (H-GLG) and high-yielding long-grain (H-YLG) rice systems in Northern Iran. The results showed that less energy is consumed in H-GLG compared to the H-YLG system. Another study 
claimed that the local rice varieties are more efficient in terms of energy consumption per land basis in comparison with high yield and hybrid varieties (AghaAlikhani et al., 2013). McFadden et al. (2013) investigated how potential carbon policies targeted at greenhouse gas emissions mitigation may affect the choice of rice varieties. They claimed that hybrid rice varieties seem more appropriate for responding to industry demand, given their higher yield per unit of GHG emission. However, there are several varieties of rice available and under cultivation in the world (Yadav et al., 2016). Therefore, it is important to compare different aspects of sustainability of rice varieties.

To date, several methods have been applied to assess the sustainability of agricultural production, including the material flow analysis (Yin et al., 2015), material circularity indicator (Rocchi et al., 2020), life cycle assessment (Lee et al., 2020), energy auditing (Bolandnazar et al., 2020), emergy analysis (Chen et al., 2006), and exergy analysis (Esmaeilpour-Troujeni et al., 2021). And more specifically, the energy auditing has been widely used to study rice production systems (Eskandari and Attar, 2015; Masuda, 2018; Rao eta 1., 2018; Habibi at al., 2019). However, the quality of inputs and the conversion process have been neglected in most energy studies in agricultural production (Yildizhan et al., 2021). In this regard, exergy analysis is receiving considerable attention as an approach to be applied for making decisions toward moving to a sustainable and energy-efficient food supply chain. It is an indicator of the quantity of useful work that can be achieved from a system when it comes to thermodynamic equilibrium with consideration of natural resources (Juárez-Hernández et al., 2019). Exergy captures the resource/environmental performance of agricultural systems through determining the real exergy dissipation, which might help farmers/policy makers moving towards a sustainable agricultural system (Zhang et al., 2019). Exergy considers the quantity and quality of energy and material flow simultaneously, and it depends on the second law of thermodynamics (Xiao et al., 2019). In other words, different types of natural resources and services in the ecosystem can be defined as a common physical unit that is an expression of quantity and quality (Hoang and Rao, 2010). Exergy analysis can be a powerful tool to analyse and identify the inefficiencies in the production process (Jawad et al., 2018). In the case of agricultural production, this indicator has been 
applied to investigate the strawberry (Yildizhan, 2018), vegetable oil (Özilgen and Sorgüven, 2011), tomato (Yildizhan and Taki, 2018), maize (Juárez-Hernández et al., 2019), wheat (Yildizhan and Taki, 2019), and apple (Yildizhan et al., 2021) production systems.

Based on the authors' knowledge, there is no published document on the effect of variety selection on the exergy flow of agricultural production. Therefore, this study focuses on how selection of variety affects the exergy flow of a crop production system (rice production) using the cumulative exergy analysis approach. In this regard, nine varieties of rice were investigated in Italy, the largest rice producer in Europe. This type of analysis helps to identify the inefficiencies in the production process of each variety and the exergy analysis results can contribute to have a better understanding of exergy (as one of the aspects of sustainability) flow of different varieties of rice in Italy. Sensitivity analysis of inputs consumption and the exergy management scenarios of the most sensitive inputs are also provided in this study.

\section{Materials and Methods}

\section{The case study, variety selection, and data collection}

In this study, nine rice (Oryza sativa L.) varieties, i.e., Balilla, Mare, Sole, Volano, Keope, Karnak, Carnaroli, Barone, and Luna were investigated. The data about the cultivation practices were collected at 9 representative rice farms located in the Po Valley Area and in the Provinces of Pavia, Vercelli, and Novara. These three provinces are responsible for about $90 \%$ of the Italian rice production. The data collection was performed by means of surveys and interview with the farmers during 2019. In detail, the information collected refers to: i) sequence and timing of field operations, ii) amount of consumed production factors (diesel, seed, organic and mineral fertilizers, pesticides, electricity), iii) mechanisation, iv) transport distance from the field to the storage point, v) water management (timing of flooding and number of aerations). The data about the mechanisation (type of tractors, self-propelled harvesters and equipment, working times, field capacity, fuel consumption) were collected according to Lovarelli and Bacenetti (2017). All the farms included in the study apply the principles of integrated agriculture (Regione Lombardia, 2020; Regione 
Piemonte, 2020), the agricultural area ranges from 63 to 560 ha (average value 93 ha) and is completely dedicate to rice cultivation. Paddy rice fields are flooded continuously during the cultivation period except for one or two short (5-7 days) aeration periods for enhancing rooting and for top fertilisation; water is removed 3 weeks before the harvest. Field operations are fully mechanised thanks to the use of 4WD tractors and combine harvesters. The yield of paddy rice and consumption of diesel fuel, gasoline, chemical fertilizer, pesticide and horn meal are reported in Table 1.

Table 1. The inventory of rice production in Italy for the different varieties.

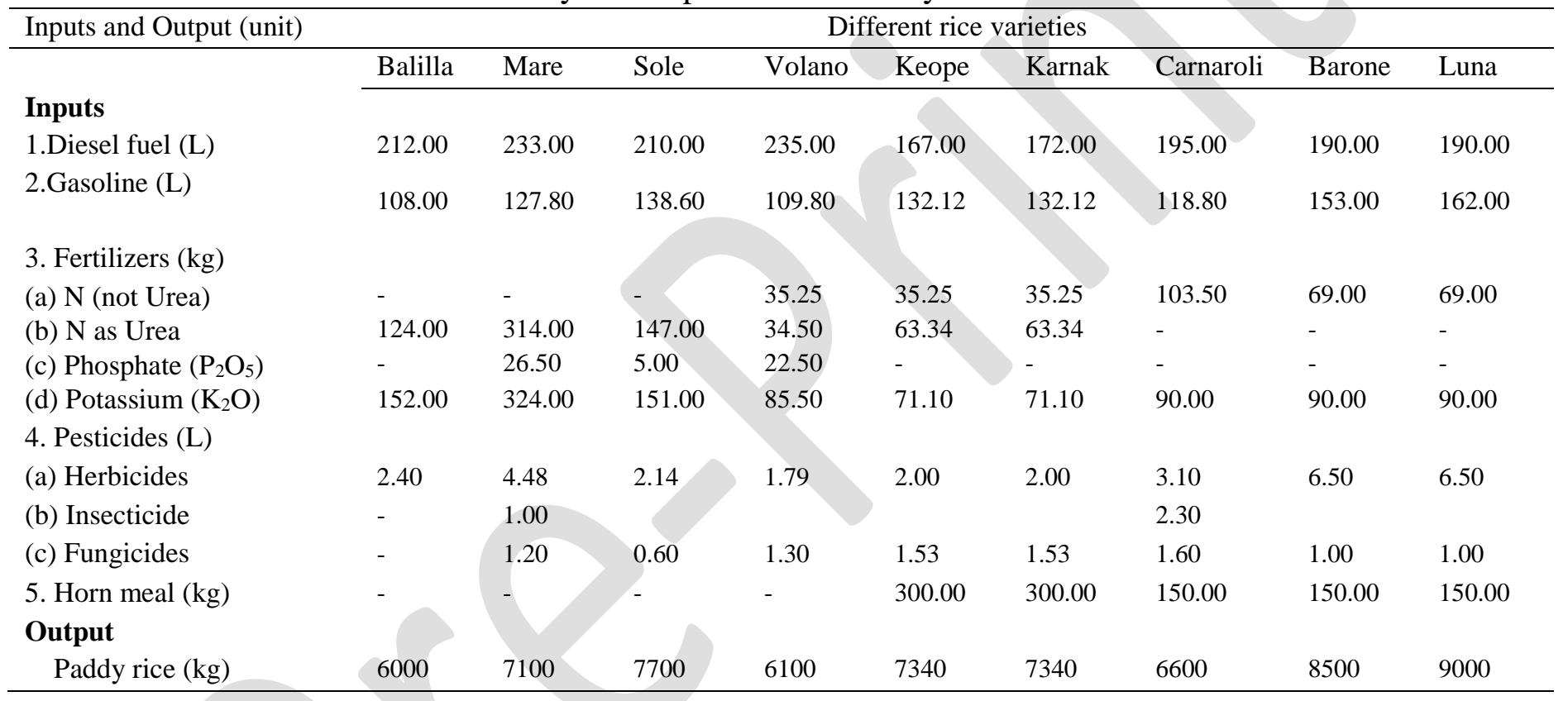

\section{Exergy analysis}

Identification and minimization of the energy losses in a system are important to find an optimized model in the agricultural production systems. Nevertheless, the conventional energy auditing methodologies, which rely on the first law of thermodynamics, are not sufficiently able to consider the quality of energy inputs and energy losses as well (Szargut, 2005). Therefore, the exergy analysis technique based on the second law of thermodynamics is developed to face this challenge. This method gives a more comprehensive investigation of inputs considering quality and losses of energies of inputs (Esmaeilpour-Troujeni et al., 2020; Wall, 2003). More specifically, it is possible 
to determine the energy efficiency for each input and to optimize the production system by identification of the energy losses through the application of the exergy analysis (Hepbasli, 2008; Rosen and Dincer, 2001). In this regard, the present study uses the cumulative exergy analysis method to investigate the different rice varieties production systems in Italy. The cumulative exergy analysis determines the total exergy consumption from all energy resources in the life cycle of the investigated process (Szargut et al., 1988; Szargut and Morris, 1987).

In this regard, the cumulative exergy consumption (CExC) for producing each rice variety was estimated, considering work and heat transfer processes in the production and processing of the inputs based on Eqs. (1) to (4) (Yildizhan, 2018):

Mass balance:

$\sum m_{\text {in }}=\sum m_{\text {out }}$

Energy balance:

$\sum(m h)_{\text {in }}-\sum(m h)_{\text {out }}=W-Q$

Exergy balance:

$\sum(m b)_{\text {in }}-\sum(m b)_{\text {out }}+\sum\left(1-\frac{T_{o}}{T_{k}}\right) Q_{k}-W=I$

Entropy balance:

$\sum \mathrm{S}_{\text {generation }}=\sum(m s)_{\text {out }}+\sum(m s)_{\text {in }}-\sum \frac{Q_{k}}{T_{k}}$

Eqs (1) and (2) refer to the law of conservation of mass and energy of various inputs consumed in a production process. In the equations, $\mathrm{Q}_{\mathrm{k}}$ and $\mathrm{W}$ are the heat transferred from system boundary and work, respectively. Moreover, $\mathrm{m}, \mathrm{h}, \mathrm{T}_{\mathrm{o}}$ and $\mathrm{T}_{\mathrm{k}}$ are mass, enthalpy and temperature at reference and boundary surfaces, respectively I and S present the irreversibility and enthalpy of the system, respectively. Besides, in Eq. (5), the term "b" also indicates the flow availability exergy for a product, in which, $b^{\text {ch }}$ and $b^{\text {th }}$ are the chemical and physical exergies, respectively (Taki and Yildizhan, 2019; Çengel and Boles, 1994).

$$
b=b^{t h}+b^{c h}
$$

With the purpose of determining the cumulative exergy of consumed inputs, the specific exergy coefficients of the inputs were used, which were obtained from the previous studies based on the law 
of conservation of mass and energy. The values of exergy equivalent for consumed inputs are presented in Table 2. The specific CExC of horn meal was assumed to be the same as farmyard manure at $5.33 \mathrm{MJ} \mathrm{kg}^{-1}$ (Özilgen and Oner, 2016), given the lack of data on specific CExC for the horn meal input. The energy coefficients of the same inputs are provided in the appendix in order to have a better understanding of the difference between energy and exergy analysis. The specific exergy value of different types of chemical fertilizers and pesticides used in producing different rice varieties differs. Therefore, to determine the $\mathrm{CExC}$ value of the fertilizers, they were divided into three groups of nitrogen (not urea), phosphate, and potassium. Likewise, pesticides were split into three groups of herbicides, fungicides, and insecticides. The total chemical exergy $\left(E x_{c}\right)$ of paddy rice was determined based on the Eq. (6) proposed by Özilgen (2018) to be $14.4 \mathrm{MJ} \mathrm{kg}^{-1}$ :

$$
E x_{c}=25.4 P+39.6 F+17.5 C
$$

where P, F, and C are the fraction of proteins, fats and carbohydrates in rice (Özilgen, 2018), which were 6.75, 1.9, and $68.5\left(\mathrm{~g} 100 \mathrm{~g}^{-1}\right)$, respectively (Chaudhari et al., 2018).

Table 2. Coefficients for calculation of cumulative exergy consumption in rice farming

\begin{tabular}{lll}
\hline Inputs (unit) & Specific CExC & References \\
\hline $\begin{array}{l}\text { 1.Diesel fuel } \\
\text { 2.Gasoline }\end{array}$ & $53.2 \mathrm{MJ} \mathrm{kg}^{-1}$ & (Szargut et al., 1988; Yildizhan et al., 2021) \\
$\begin{array}{l}\text { 3. Biocides } \\
\text { (a) Herbicides }\end{array}$ & $35.6 \mathrm{MJ} \mathrm{kg}^{-1}$ & (Szargut et al., 1988) \\
& $32.7 \mathrm{MJ} \mathrm{kg}^{-1}$ & (Pimentel, 1991; Esmaeilpour-Troujeni et al., 2021) \\
(b) Pesticides & $7.52 \mathrm{MJ} \mathrm{kg}^{-1}$ & (Brehmer, 1991; Esmaeilpour-Troujeni et al., 2021) \\
(c) Fungicides & $4.56 \mathrm{MJ} \mathrm{kg}^{-1}$ & (Pimentel, 1991; Esmaeilpour-Troujeni et al., 2021) \\
$\begin{array}{l}\text { 4.Fertilizers } \\
\text { (a) Nitrogen }\end{array}$ & $32.7 \mathrm{MJ} \mathrm{kg}^{-1}$ & (Szargut et al., 1988; Yildizhan et al., 2021) \\
(b) Phosphate $\left(\mathrm{P}_{2} \mathrm{O}_{5}\right)$ & $7.52 \mathrm{MJ} \mathrm{kg}^{-1}$ & (Wittmus et al., 1975; Yildizhan et al., 2021) \\
(c) Potassium $\left(\mathrm{K}_{2} \mathrm{O}\right)$ & $4.56 \mathrm{MJ} \mathrm{kg}^{-1}$ & (Pimentel, 1991; Yildizhan et al., 2021) \\
\hline
\end{tabular}

\section{RI and CDP calculation}

In the next step, the cumulative degree of perfection (CDP) and renewability indicator (RI) indices were applied for a comparative analysis of the investigated rice varieties systems. CDP contributes to determining the relation between the exergy value of the final product and the CExC of inputs (Amiri et al., 2020). Higher value of CDP in each rice variety indicates lower exergy losses (high 
exergy performance) in the production process. The CDP index was calculated using Eq. 7, according to Szargut et al., 1988, which is the chemical exergy of the final product (paddy rice in this study) to the total exergy of the inputs.

$$
C D P=\frac{\text { Exergy of rice }}{\sum(\mathrm{CExC})}
$$

The RI index was determined using Eq. 8 based on the concept of restoration. This index was estimated based on the total chemical exergy of final product $\left(E_{\mathrm{ch}}\right)$ and the total renewable energy resources used in the production and wastes disposal (W) (Pelvan and Özilgen, 2017; Esmaeilpour et al., 2021):

$$
R I=\frac{\left(E_{c h}-W\right)}{E_{c h}}
$$

Fig. 1 illustrates the four possible levels of RI index. The RI index of $0<\mathrm{RI}<1$ and RI = 1 indicates the process is partially renewable and fully renewable, respectively.

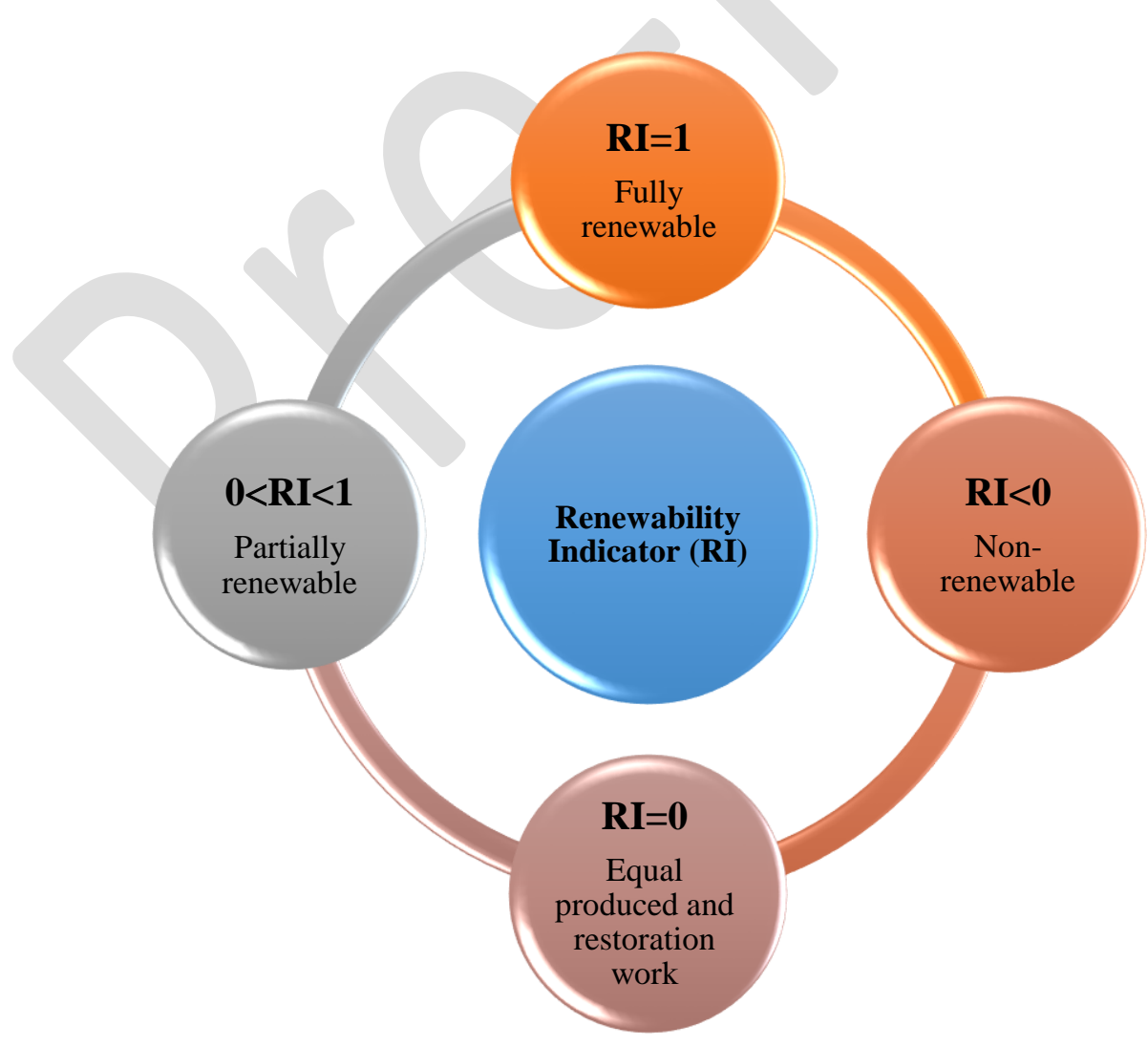

Fig. 1. Four different levels of renewability indicator (Berthiaume et al., 2001). 


\section{Sensitivity analysis and exergy management scenarios}

Sensitivity analysis of inputs consumption is also done in this study. In this regard, the effect of a $10 \%$ reduction in the amount of exergy consumed in each input on the exergy indices (CExC, CDP, and RI) of the investigated system was quantified. Subsequently, seven scenarios were developed to evaluate the effects of replacement of the most sensitive inputs with an environmentally friendly input on the exergy indices of paddy rice production system. The applied scenarios were scenario 1: using corn-based ethanol as an alternative to gasoline; scenario 2: using soybean-based biodiesel as an alternative to diesel; scenario 3: rapeseed-based biodiesel as an alternative to diesel; scenario 4: algaebased biodiesel as an alternative to diesel; scenario 5: corn-based ethanol as an alternative to gasoline and use of soy-based biodiesel as an alternative to diesel; scenario 6: corn-based ethanol as an alternative to gasoline and rapeseed-based biodiesel as an alternative to diesel, and scenario 7: cornbased ethanol as an alternative to gasoline and algae-based biodiesel as an alternative to diesel.

\section{Results and discussion}

\section{Cumulative exergy consumption}

Fig. 2 shows the cumulative exergy consumption of nine rice varieties in Italy. Mare variety had the highest CExC among the investigated varieties due to its huge diesel fuel and chemical fertilizer footprints. The CExC of fertilizers for the above-mentioned variety was around two times more than the other investigated varieties. On the other hand, the lowest $\mathrm{CExC}$ were belonged to the Keope and Barone varieties with the values of 16,096 and $16,137 \mathrm{MJ} \mathrm{ha}^{-1}$, respectively, given the relatively low amount of CExC of diesel fuel in Keope variety and amount of chemical fertilizers in Barone variety. Diesel fuel was the largest contributor to the $\mathrm{CExC}$ of all investigated rice varieties production systems except Mare variety. For instance, the CExC of this input for Volano and Mare varieties were 10502 and $10412 \mathrm{MJ} \mathrm{ha}^{-1}$, respectively, due to relatively high usage of agricultural machinery which can cause a larger amount of fuel consumption. The highest hours of agricultural machinery usage 
belonged to the Volano variety production system with $25.5 \mathrm{~h} \mathrm{ha}^{-1}$ followed by Mare with $21.5 \mathrm{~h} \mathrm{ha}^{-}$ 1.

Chemical fertilizer was the second-largest contributor to the total energy consumption. The CExC of chemical fertilizer (11,945 $\left.\mathrm{MJha}^{-1}\right)$ within the Mare variety production system was remarkably high, according to Fig 2. The lowest CExC of this input belonged to the Luna and Barone varieties (2667 $\mathrm{MJha}^{-1}$ ). The largest percentage of CExC of chemical fertilizers attributed to nitrogen-based chemical fertilizers, specifically urea. In this regard, using non-urea-based fertilizer for Luna and Barone production contributes to reduction of CExC. Yaldizhan and Taki, (2019) reported that the largest share of CExC in wheat production was attributed to the chemical fertilizer input with the largest share of nitrogen-based fertilizer. Yildizhan and Taki, (2019) also claimed that the chemical fertilizer input was one of the main contributor to the CExC. Nitrogen has a crucial role in increasing crop yields (Ahmad et al., 2005). Appropriate application of nitrogen-based fertilizers can significantly help for the reduction of nitrogen consumption.

Gasoline was the third contributor to the total CExC for all the nine investigated varieties. This input is mainly consumed to fuel the machines to transport the input-output. Luna was the largest consumer of gasoline with a CExC of 4,268 $\mathrm{MJha}^{-1}$; however, Balila was identified as the lowest gasoline consumer with CExC of $2845 \mathrm{MJ} \mathrm{ha}^{-1}$. The results are in agreement with other studies (Yildizhan and Taki, 2019; Özilgen and Sorgüven, 2011; Esmaeilpour-Troujeni et al., 2020) showing the huge CExC footprint of fossil fuels in crop production. Fossil fuels are also reported as one of the largest contributors to $\mathrm{CExC}$ of greenhouse-based agricultural production systems, mainly for heating the greenhouses (Yildizhan, 2018; Taki and Yildizhan, 2018). 


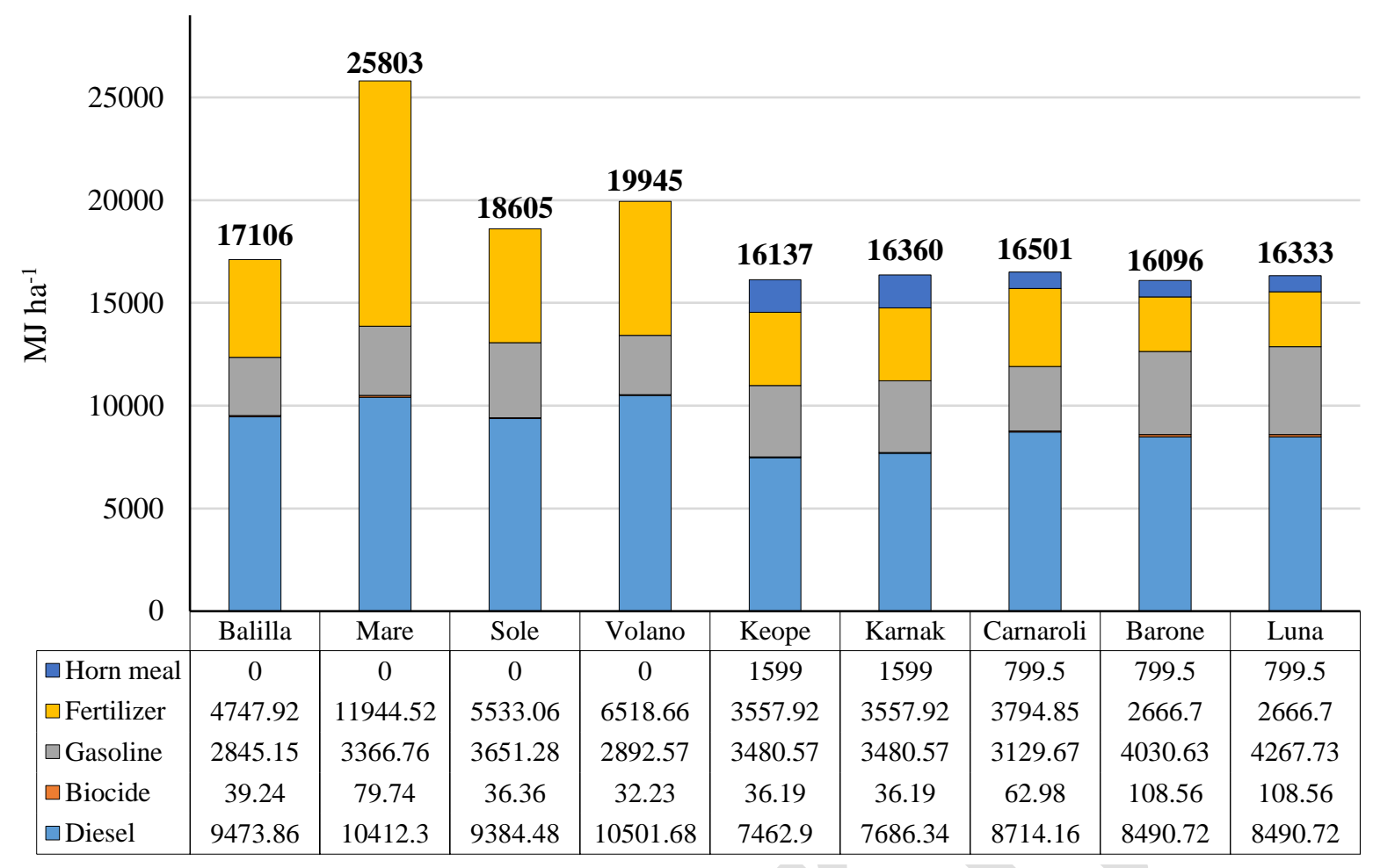

Fig. 2. Cumulative exergy consumption for different rice varieties in Italy

Biocides were identified as one of the least consumers of exergy in the investigated rice varieties. In the wheat and rapeseed production systems in Iran (Yildizhan and Taki, 2019; Esmaeilpour-Troujeni et al., 2020) and tomato production in Turkey (Yildizhan, 2018), the lowest CExC value belonged to the biocides. In the case of biocides for rice production, Barone and Luna varieties had the highest amounts of $\mathrm{CExC}$, while the Volano variety had the lowest $\mathrm{CExC}$ of the biocides with $32 \mathrm{MJha}^{-1}$. Herbicides were the highest and insecticides were the lowest contributors to the CExC According to Fig. 2(b).

The horn meal input was not used in the process of Balilla, Mare, Volano, and Sole rice production. Fig. 2 and Fig. 3(a) indicate that the CExC amount of chemical fertilizer input was huge for those rice varieties that the horn meal was not used in the production process. On the contrary, the CExC of the chemical fertilizer input in those production systems that used horn meal was remarkably lower. The results reveal that the balanced utilization of organic and chemical fertilizers in the production system can significantly reduce the CExC of the system. Several previous studies also claimed that the use of organic fertilizers could lead to a reduction of chemical fertilizer consumption, and consequently decreasing the CExC of the system (Roy and Singh, 2006; Megawar and Mahfouz, 
2010). On the other hand, it should be considered that the use of organic fertilizer in flooded paddy fields increases the methane emission and, consequently, the carbon footprint of rice (Fusi et al., 2017).

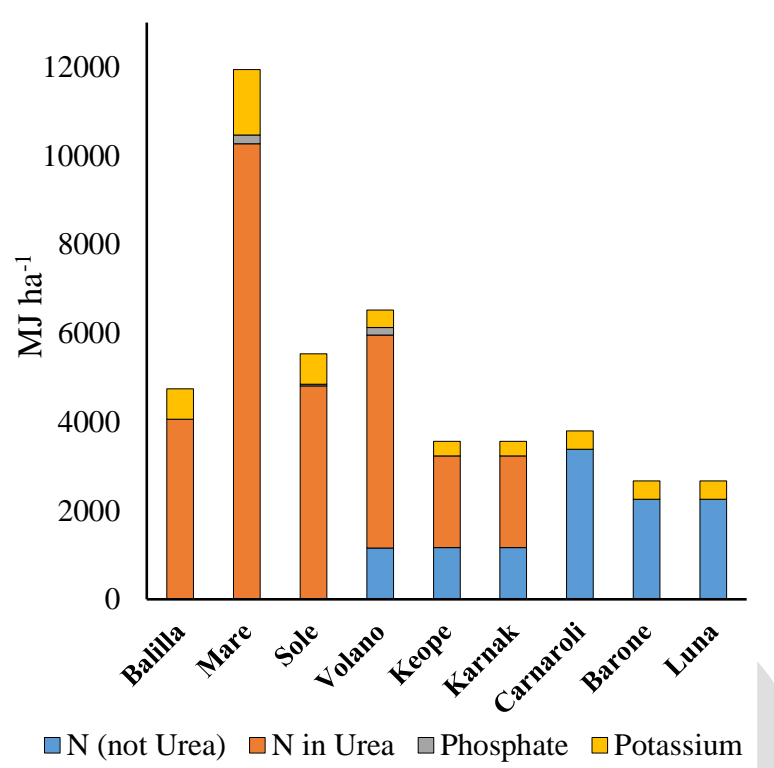

a (CExC chemical fertilizers)

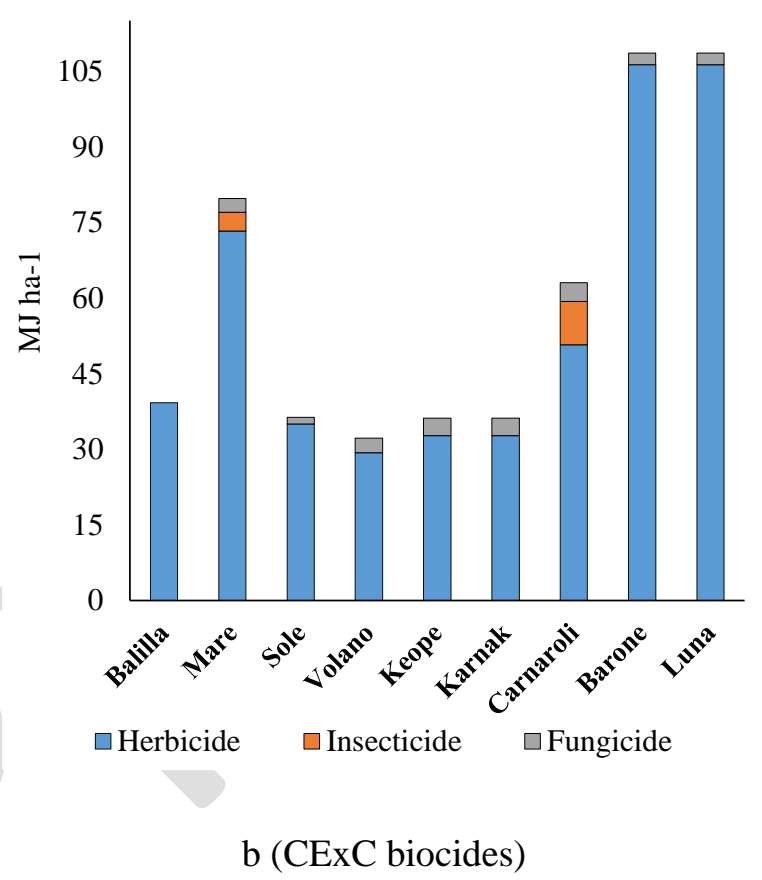

(b) biocides for different rice varieties

\section{RI and CDP}

Luna and Barone varieties had the highest CDP values with 7.96 and 7.63, respectively, while Mare variety had the lowest CDP with 3.98. Therefore, Luna was known as the variety with the lowest exergy losses and consequently, the most sustainable variety among the investigated varieties of rice in Italy in terms of exergy. The results also pointed out that for a given amount of rice produced in the systems, the CExC of Luna and Barone were the lowest, and thus, the production process of the varieties was more environmentally-friendly than other investigated rice varieties. In the study on wheat production systems, Yildizhan and Taki (2019) also reported that the CDP of the rain-fed system with 6.48 was more than that of the irrigated system with 2.9 , due to the higher CExC of the irrigated system. The study on the sustainability of different rapeseed production systems also revealed that the semi-mechanized system with a higher sustainability index, had the lower CExC 
value (Esmaeilpour-Troujeni et al., 2020). Another important reason for the difference in CDP indices in different rice varieties was the difference in the amount of output exergy of the varieties. According to Table 1, Luna and Barone varieties had the highest, and Volano and Mare varieties had the lowest yield, and as a result, lower output exergy. The comparison of the above-mentioned results with the present research findings indicated that the CDP index in the production of the Luna variety in Italy was higher than that of the wheat and rapeseed systems. This could be due to different growing conditions and differences in the exergy output coefficients of these crops. The CDP index for cucumber production (Taki and Yildizhan, 2018), strawberry (Yildizhan, 2018), and tomato (Yildizhan and Taki, 2018) in Turkey was estimated at $0.23,0.29$, and 1.62 , respectively.

The renewability index was also applied to investigate the sustainability of rice production. According to Fig. 4, Luna and Barone varieties had the highest RI values with 0.88 , while Mare variety with 0.75 had the lowest RI value. It revealed that rice production in Italy was partially renewable. The main reason for the difference in RI between different varieties was the difference in the amount of non-renewable inputs used in producing these varieties. The RI value was the lowest in Volano and Mare varieties with the highest CExC of non-renewable inputs (diesel fuel, gasoline, fertilizers, and biocides), while Luna, Barone, Karnak, and Keope varieties, in which the CExC values of nonrenewable inputs were estimated to be lower, had higher RI values. In comparison to some other crops, the index was higher in Luna and Barone varieties than rapeseed $\left(\mathrm{RI}_{\mathrm{Max}}=0.731\right)$ and wheat $(\mathrm{RI}=0.65)($ Esmaeilpour-Troujeni et al., 2020; Yildizhan and Taki, 2019).

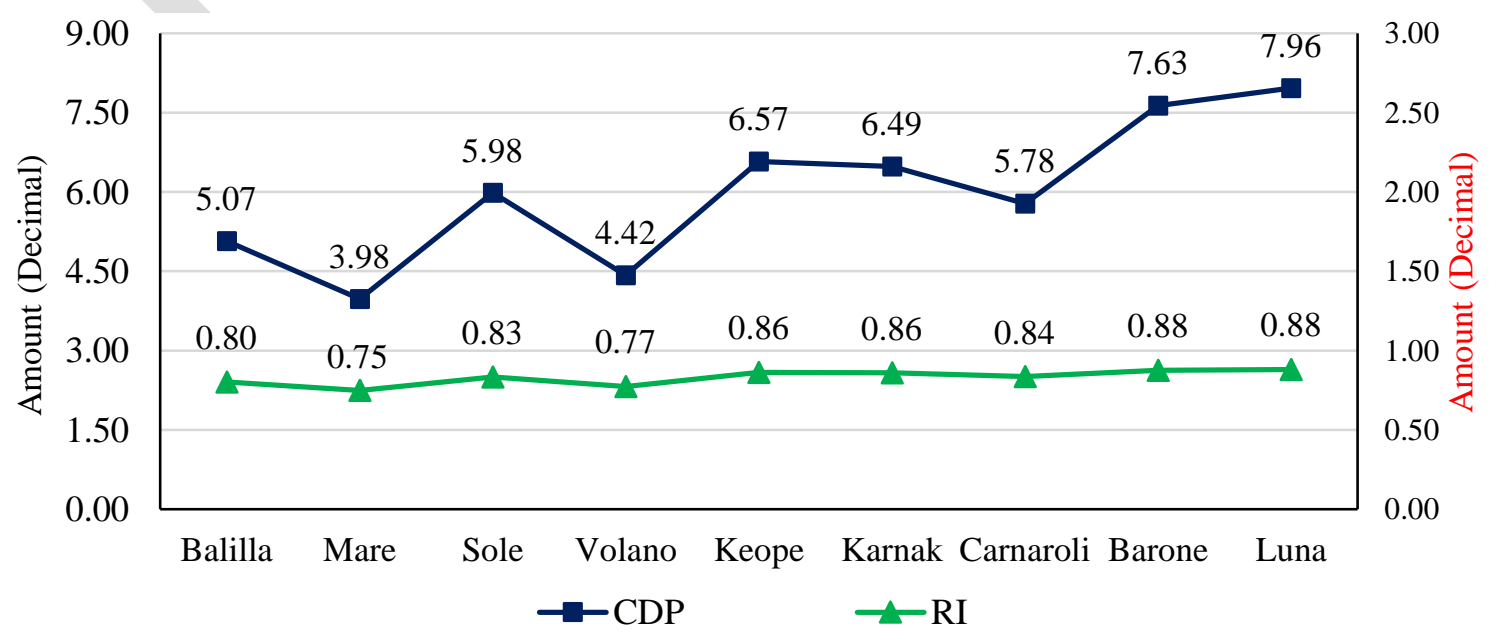


Fig. 4. CDP and RI values of different rice varieties production systems

\section{Sensitivity analysis}

Table 3 presents the results obtained from the sensitivity analysis of inputs consumed for producing different rice varieties based on the applied energy indices i.e., CExC, CDP and RI. According to the results of $\mathrm{CExC}$, diesel fuel, chemical fertilizers, and gasoline had the most significant effects on the $\mathrm{CExC}$ value of different rice varieties, respectively. On the other hand, a $10 \%$ reduction in the amount of exergy consumed in each of these inputs caused a significant decrease in CExC value in all rice varieties. Fig. 1 also reported the importance of these inputs in increasing the CExC value, and the inputs with the largest impacts on increasing the CExC. Moreover, the diesel fuel, chemical fertilizers and gasoline inputs had the highest impact on increasing the CDP and RI indices. On the other hand, a $10 \%$ reduction in the amount of exergy consumed in each of these inputs led to increasing CDP and RI indices significantly. Overall, the results of the sensitivity analysis highlighted that diesel fuel, chemical fertilizers and gasoline had the major impacts on the CExC, CDP and RI. Fossil fuels are the major widely used inputs in various rice varieties production systems due to their contribution to various agricultural operations (tillage, transplanting, farm management, harvesting, and transportation).

Table 3. The sensitivity analysis of consumed inputs for investigated rice varieties

\begin{tabular}{|c|c|c|c|c|c|c|c|c|c|}
\hline \multirow[t]{2}{*}{ Inputs } & \multicolumn{9}{|c|}{ CExC (MJ ha-1) } \\
\hline & Balilla & Mare & Sole & Volano & Keope & Karnak & Carnaroli & Barone & Luna \\
\hline All & 17106 & 25803 & 18605 & 19945 & 16137 & 16360 & 16501 & 16096 & 16333 \\
\hline All minus ten percent diesel & 16158 & 24762 & 17667 & 18895 & 15390 & 15591 & 15629 & 15247 & 15484 \\
\hline All minus ten percent biocide & 17102 & 25795 & 18601 & 19942 & 16133 & 16356 & 16494 & 16085 & 16322 \\
\hline All minus ten percent gasoline & 16821 & 25466 & 18240 & 19656 & 15788 & 16012 & 16188 & 15693 & 15906 \\
\hline All minus ten percent fertilizers & 16631 & 24609 & 18052 & 19293 & 15781 & 16004 & 16121 & 15829 & 16067 \\
\hline All minus ten percent horn meal & 17106 & 25803 & 18605 & 19945 & 15977 & 16200 & 16421 & 16016 & 16253 \\
\hline \multirow[t]{2}{*}{ All minus ten percent CExC } & 15395 & 23223 & 16745 & 17951 & 14523 & 14724 & 14851 & 14486 & 14700 \\
\hline & \multicolumn{9}{|c|}{$\mathrm{CDP}$} \\
\hline All & 5.07 & 3.98 & 5.98 & 4.42 & 6.57 & 6.49 & 5.78 & 7.63 & 7.96 \\
\hline All minus ten percent diesel & 5.37 & 4.14 & 6.30 & 4.67 & 6.89 & 6.80 & 6.10 & 8.06 & 8.40 \\
\hline All minus ten percent biocide & 5.07 & 3.98 & 5.98 & 4.42 & 6.58 & 6.49 & 5.78 & 7.64 & 7.97 \\
\hline All minus ten percent gasoline & 5.17 & 4.05 & 6.11 & 4.50 & 6.72 & 6.63 & 5.90 & 7.83 & 8.18 \\
\hline All minus ten percent fertilizers & 5.21 & 4.17 & 6.17 & 4.57 & 6.72 & 6.63 & 5.92 & 7.76 & 8.10 \\
\hline All minus ten percent horn meal & 5.07 & 3.98 & 5.98 & 4.42 & 6.64 & 6.55 & 5.81 & 7.67 & 8.00 \\
\hline All minus ten percent CExC & 5.63 & 4.42 & 6.65 & 4.91 & 7.31 & 7.21 & 6.42 & 8.48 & 8.85 \\
\hline
\end{tabular}




\begin{tabular}{llllllllll}
\hline & \multicolumn{1}{c}{ RI } \\
\cline { 2 - 10 } All & 0.80 & 0.75 & 0.83 & 0.77 & 0.86 & 0.86 & 0.84 & 0.88 & 0.88 \\
All minus ten percent diesel & $\mathbf{0 . 8 1}$ & $\mathbf{0 . 7 6}$ & $\mathbf{0 . 8 4}$ & $\mathbf{0 . 7 9}$ & $\mathbf{0 . 8 7}$ & $\mathbf{0 . 8 7}$ & $\mathbf{0 . 8 4}$ & $\mathbf{0 . 8 8}$ & $\mathbf{0 . 8 9}$ \\
All minus ten percent biocide & 0.80 & 0.75 & 0.83 & 0.77 & 0.86 & 0.86 & 0.84 & 0.88 & 0.88 \\
All minus ten percent gasoline & $\mathbf{0 . 8 1}$ & $\mathbf{0 . 7 5}$ & $\mathbf{0 . 8 4}$ & $\mathbf{0 . 7 8}$ & $\mathbf{0 . 8 7}$ & $\mathbf{0 . 8 6}$ & $\mathbf{0 . 8 4}$ & $\mathbf{0 . 8 8}$ & $\mathbf{0 . 8 8}$ \\
All minus ten percent fertilizers & $\mathbf{0 . 8 1}$ & $\mathbf{0 . 7 6}$ & $\mathbf{0 . 8 4}$ & $\mathbf{0 . 7 8}$ & $\mathbf{0 . 8 7}$ & $\mathbf{0 . 8 6}$ & $\mathbf{0 . 8 4}$ & $\mathbf{0 . 8 8}$ & $\mathbf{0 . 8 8}$ \\
All minus ten percent horn meal & 0.80 & 0.75 & 0.83 & 0.77 & 0.86 & 0.86 & 0.84 & 0.88 & 0.88 \\
All minus ten percent CExC & 0.82 & 0.77 & 0.85 & 0.80 & 0.88 & 0.87 & 0.85 & 0.89 & 0.89 \\
\hline
\end{tabular}

* The bold values represent the inputs with the largest impact on the investigated indicators.

\section{CExC in the proposed scenario}

As the results of the sensitivity analysis indicated that the two inputs of diesel fuel and gasoline had the significant impacts on reducing the $\mathrm{CExC}$ in all investigated varieties. In addition, since these two inputs are among the non-renewable inputs, the consumption rate of them can be highly influential in estimating the RI index. In this case, if biofuels are used as a substitute for fossil fuels, then the share of non-renewable-based energy sources could be remarkably mitigated. Therefore, in this study, the use of corn-based ethanol was considered as a substitute for gasoline and three biodiesels (algaebased, soybean-based, and rapeseed-based) were considered as alternatives to diesel fuel. Considering the values of $6.36 \mathrm{MJ} \mathrm{kg}^{-1}, 8.8 \mathrm{MJ} \mathrm{kg}^{-1}, 8.94 \mathrm{MJ} \mathrm{kg}^{-1}$, and $22.99 \mathrm{MJ} \mathrm{kg}^{-1}$, respectively for the specific exergy coefficient of corn-based ethanol, algae-based biodiesel, soybean-based biodiesel, and rapeseed-based biodiesel, the use of biofuels as a substitute for fossil fuels was investigated in seven different scenarios.

Fig. 5(a) indicates the CExC values of the recommended scenarios for different rice varieties. According to the results, the CExC values of the scenarios were significantly lower than the conventional system in all investigated varieties. The CExC values of S6 and S7 had the highest decrease compared to the other scenarios. According to Fig. 5(b) in these two scenarios, the CExC value could be saved up to $44 \%$ for Mare variety and up to $65 \%$ for two varieties of Barone, and Luna. The results also reveal that although the amount of $\mathrm{CExC}$ in $\mathrm{S} 1$ had the lowest decrease among the studied scenarios, the amount of exergy that could be saved in this scenario was significant. Thus, according to Fig. 5(b), in S1, the CExC value could be saved from $11 \%$ for Mare variety to $21 \%$ for Luna and Barone varieties. Overall, the results indicated that the use of corn-based ethanol instead of 
gasoline and the use of rapeseed and algae-based biodiesel instead of diesel fuel had the greatest effect on reducing the $\mathrm{CExC}$ of different rice varieties production in Italy. The results were in line with Yildizhan and Taki (2019) study on rain-fed and irrigated wheat production systems which showed the use of biofuels instead of fossil fuels significantly reduced the CExC in both systems. The results of investigating the mechanized and semi-mechanized rapeseed production also revealed that using algae-based biodiesel as a substitute for diesel fuel and using solar energy as a substitute for the electricity source, reduced the CExC value by $31 \%$ in the mechanized system and by $29 \%$ in the semi-mechanized system (Esmaeilpour-Troujeni et al., 2020).

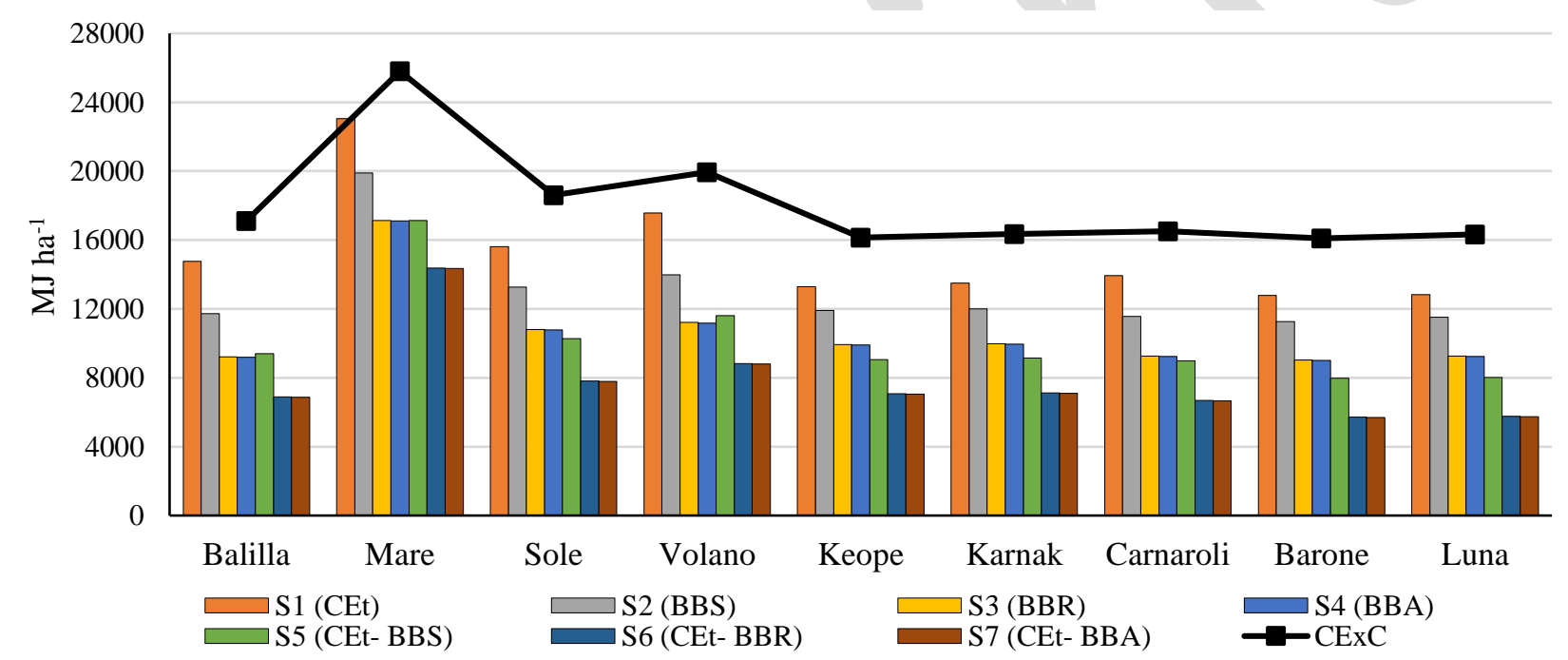

(a)

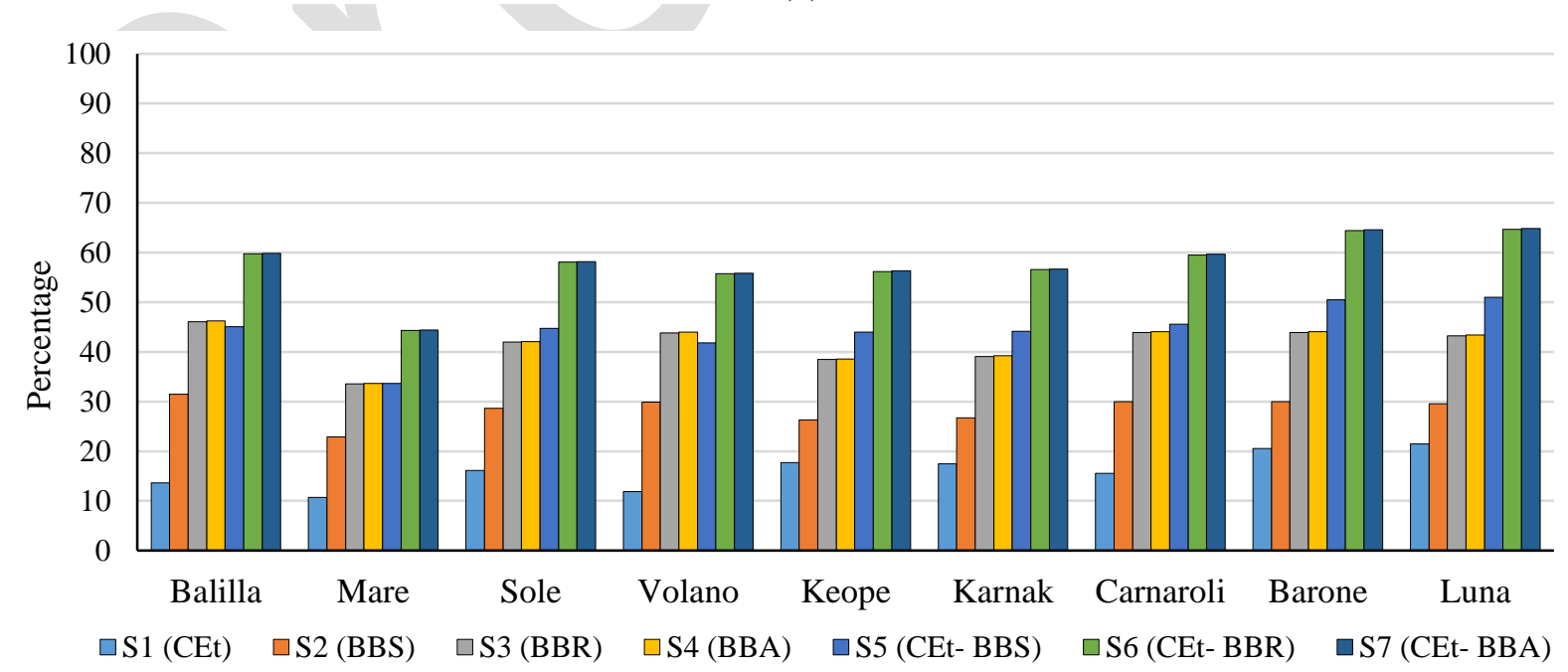

(b)

Fig. 5. The CExC value (a), and percentage of savable exergy (b) in the new modes for different rice varieties 
Scenario1 (S1): corn-based ethanol as an alternative to gasoline (CEt). Scenario2 (S2): soybean-based biodiesel as an alternative to diesel (BBS). Scenario3 (S3): rapeseed-based biodiesel as an alternative to diesel (BBR). Scenario4 (S4): algae-based biodiesel as an alternative to diesel (BBA). Scenario5 (S5): corn-based ethanol as an alternative to gasoline and the use of soy-based biodiesel as an alternative to diesel (CEt- BBS). Scenario6 (S6): corn-based ethanol as an alternative to gasoline and use rapeseed-based biodiesel as an alternative to diesel (CEt- BBR). Scenario7 (S7): corn-based ethanol as an alternative to gasoline and algae-based biodiesel as an alternative to diesel (CEt- BBA).

\section{CDP and RI indices in the proposed scenario}

Fig. 6 presents the CDP and RI values in the current and recommended scenarios for different rice varieties. The CDP values of the recommended scenarios for all rice varieties increased significantly compared to the conventional system, which was the highest in S7. Thus, the CDP value in this scenario increased significantly from 7.15 for Mare variety to 22.64 for Luna variety compared to the conventional mode. The increase in CDP of the investigated scenarios revealed that for a given amount of rice production, the CExC value decreased in the recommended modes. The results also indicated that the RI values of the studied scenarios increased significantly compared to the conventional mode in all rice varieties (Fig. 6(b)). The RI values of S6 and S7 had the largest increase compared to other scenarios. As in both scenarios, the RI increased from 0.86 for the Mare variety to 0.96 for the Barone and Luna varieties.

Increasing RI value in the recommended scenarios means the increase of using renewable energies in the production process and consequently having a more environmentally-friendly process. Overall, the results indicated that the application of corn-based ethanol instead of gasoline and the use of rapeseed-based biodiesel instead of diesel fuel had the highest impact on increasing both CDP and RI indices in the production of different rice varieties in Italy. Moreover, according to the results, Luna variety had the highest, and Mare variety had the lowest increase in the renewable energies usage. In this regard, in various other studies on crops production, the results highlighted that application of renewable energies instead of fossil fuels led to increasing the RI and CDP indices in the production process (Esmaeilpour-Troujeni et al., 2020; Taki and Yildizhan, 2018; Pelvan and Öilzilgen, 2017). There are also some other ways for moving toward a sustainable rice production system. For instance, a study showed rice ratooning is more eco-efficient than the single cropping system (Firouzi et al., 
2018). Khoshnevisan et al. (2021) indicated that $355 \%$ reduction in global warming impact could be achieved under optimal rice-crab co-culture system compared to rice mono-culture.

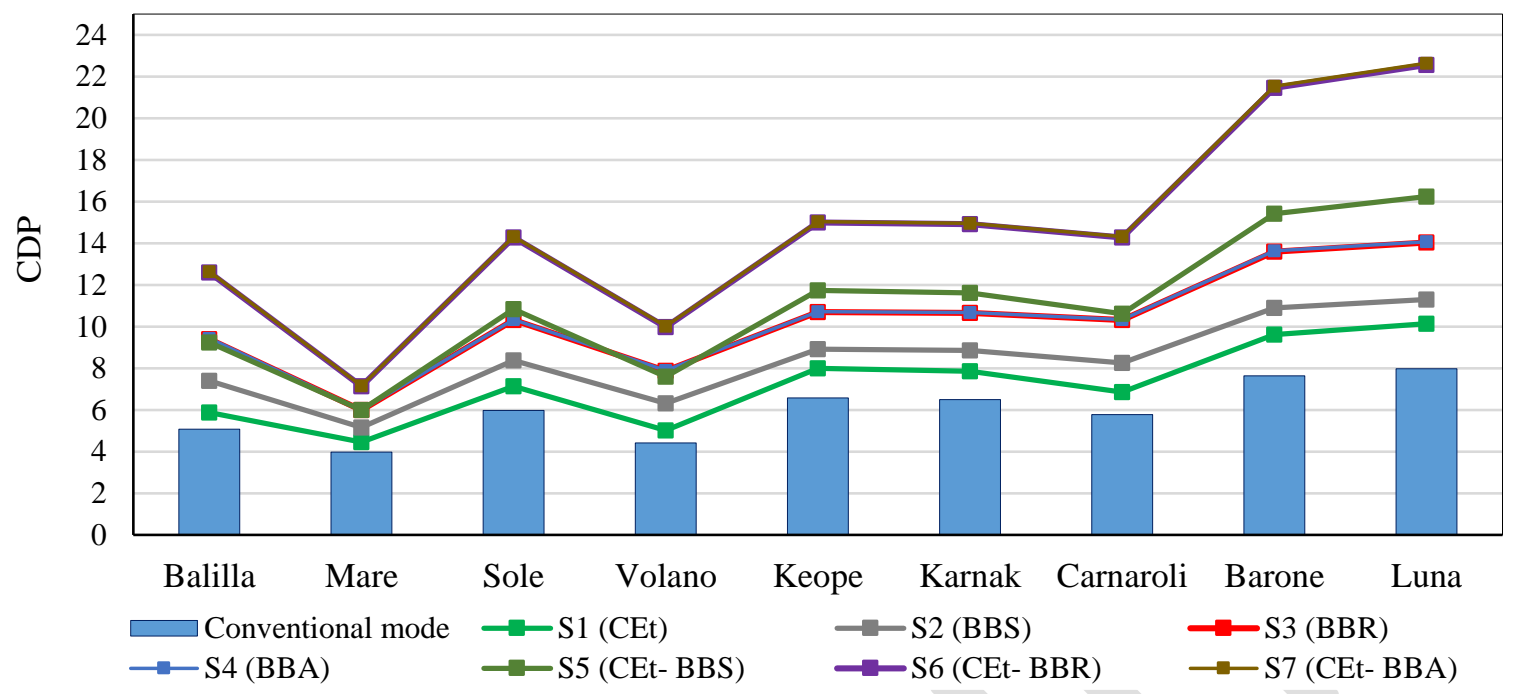

(a)

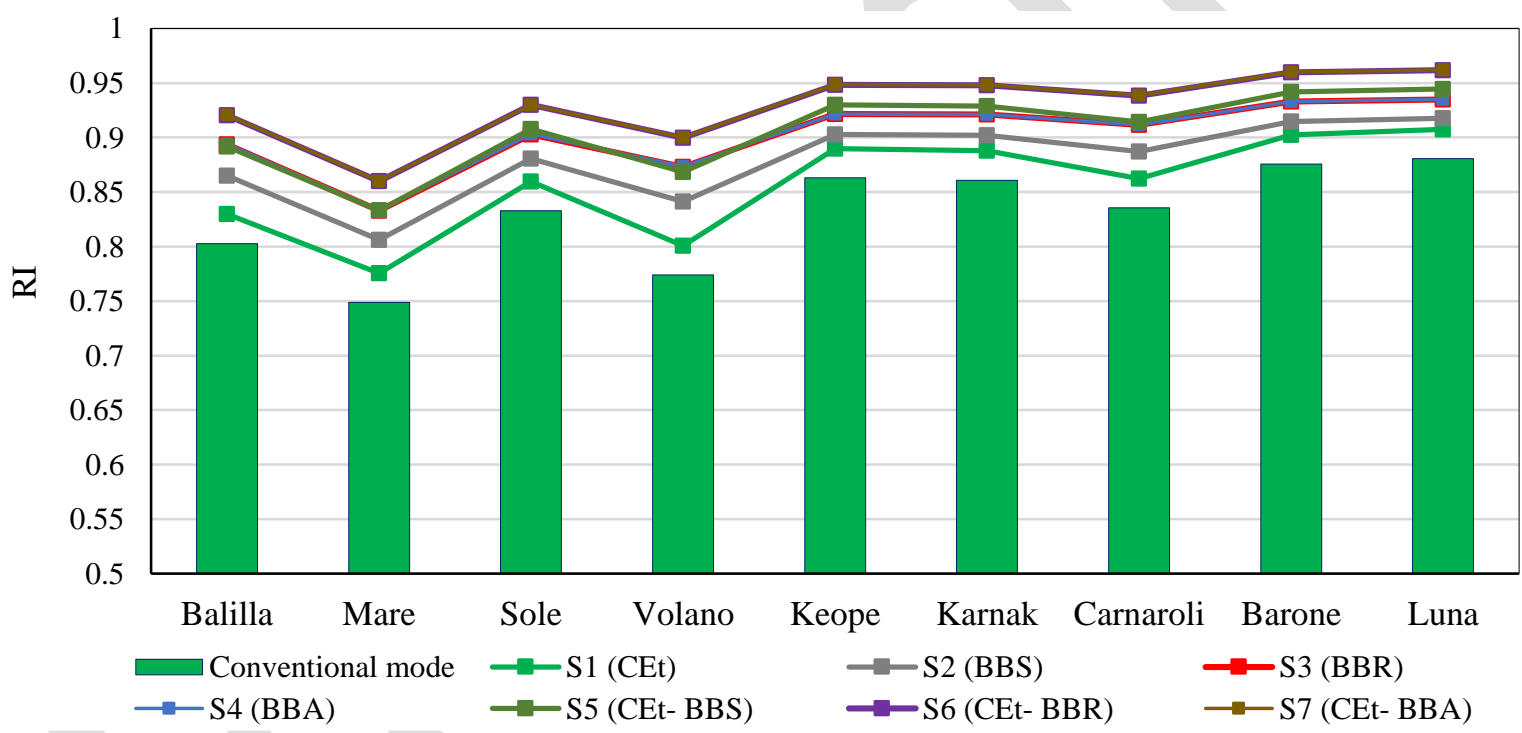

(b)

Fig. 6. The (a) CDP and (b) RI of the recommended scenarios for different rice varieties

Scenario1 (S1): Using corn-based ethanol as an alternative to gasoline (CEt). Scenario2 (S2): Using soybean-based biodiesel as an alternative to diesel (BBS). Scenario3 (S3): Using rapeseed-based biodiesel as an alternative to diesel (BBR). Scenario4 (S4): Using algae-based biodiesel as an alternative to diesel (BBA). Scenario5 (S5): Using corn-based ethanol as an alternative to gasoline and use of soy-based biodiesel as an alternative to diesel (CEt- BBS). Scenario6 (S6): Using corn-based ethanol as an alternative to gasoline and use rapeseed-based biodiesel as an alternative to diesel (CEt- BBR). Scenario7 (S7): Using corn-based ethanol as an alternative to gasoline and use algae-based biodiesel as an alternative to diesel (CEt- BBA).

\section{Conclusion}

There are multiple criteria affecting the sustainability of agricultural system. In this regard, exergy is getting attention as an indicator that can be considered toward moving to a sustainable food production system. Since selection of crop variety might affect agricultural production's sustainability, this study 
focused on the effect of selection of variety on the exergy flow of rice (as an essential agricultural product) in Italy (the largest rice producer in Europe). In this regard, cumulative exergy consumption (CExC), cumulative degree of perfection (CDP), and renewability index (RI) were evaluated as the exergy indices. The results showed that there is a difference between the exergy indices of the investigated rice varieties; for instance, the $\mathrm{CExC}$ value of the investigated rice varieties ranges from 16.09 to $25.80 \mathrm{GJha}^{-1}$. The CDP value of the rice varieties also varied from 3.98 to 7.96 , and RI were determined to be between 0.75 to 0.88 .

The results of the sensitivity analysis showed that fossil fuels (diesel fuel and gasoline) had the significant impacts on the $\mathrm{CExC}$ and as a result, on the sustainability of all investigated rice varieties production systems. Therefore, in the present study, replacing fossil fuels by biofuels was proposed as an alternative to decrease the share of non-renewable energy sources. Thus, the use of corn-based ethanol was considered as a substitute for gasoline and three biodiesels of algae-based, soybean-based, and rapeseed-based were considered as alternatives to diesel fuel. The results indicated that using biofuels could contribute to $\mathrm{CExC}$ reduction in the investigated rice varieties systems. It also can result in a significant increase in the CDP and RI indices of all production systems for different rice varieties. In conclusion, the results revealed that the sustainability of rice production systems can differ based on the crop variety due to different needs to inputs consumption and different yields. In addition, replacing non-renewable energy resources by renewable ones could lead to saving the exergy of the systems and leading to a sustainable and energy/exergy-efficient food supply chain. Further research is needed to explore the aspects of sustainability of different varieties of rice production systems, including water footprint, social and economic.

\section{References}

AghaAlikhani, M., Kazemi-Poshtmasari, H. and Habibzadeh, F., 2013. Energy use pattern in rice production: A case study from Mazandaran province, Iran. Energy Conversion and Management, 69, 157-162.

Ahmad, A., Khan, I., Anjum, N. A., Abrol, Y. P., \& Iqbal, M. (2005). Role of sulphate transporter systems in sulphur efficiency of mustard genotypes. Plant Science, 169(5), 842-846. 
Amanullah, K. and Fahad, S. eds., 2017. Rice: Technology and Production. BoD-Books on Demand.

Amiri, Z., Asgharipour, M.R., Campbell, D.E. and Armin, M., 2020. Extended exergy analysis (EAA) of two canola farming systems in Khorramabad, Iran. Agricultural Systems, 180, p.102789.

Bacenetti, J., Fusi A., Negri, M., Fiala, M., Bocchi, S. 2016. Organic production systems: Sustainability assessment of rice in Italy. Agricultural Ecosystems and Environment, 225, 33-44.

Belitz, H. D., Grosch, W., \& Schieberle, P. (2009). Cereals and cereal products. Food chemistry, 670745 .

Berthiaume, R., Bouchard, C., \& Rosen, M. A. (2001). Exergetic evaluation of the renewability of a biofuel. Exergy, An International Journal, 1(4), 256-268.

Bolandnazar, E., Rohani, A. and Taki, M., 2020. Energy consumption forecasting in agriculture by artificial intelligence and mathematical models. Energy Sources, Part A: Recovery, Utilization, and Environmental Effects, 42(13), pp.1618-1632.

Çengel, Y.A. and Boles, M.A. (1994) Thermodynamics: an Engineering Approach, pp.67-68, McGraw-Hill, New York, USA.

Chapagain, A.K. and Hoekstra, A.Y., 2011. The blue, green and grey water footprint of rice from production and consumption perspectives. Ecological Economics, 70(4), 749-758.

Chaudhari, P. R., Tamrakar, N., Singh, L., Tandon, A., \& Sharma, D. 2018. Rice nutritional and medicinal properties: A. Journal of Pharmacognosy and Phytochemistry, 7(2), 150-156.

Chen, G.Q., Jiang, M.M., Chen, B., Yang, Z.F. and Lin, C., 2006. Emergy analysis of Chinese agriculture. Agriculture, Ecosystems \& Environment, 115(1-4), 161-173.

Clauss, K., Ottinger, M., Leinenkugel, P. and Kuenzer, C., 2018. Estimating rice production in the Mekong Delta, Vietnam, utilizing time series of Sentinel-1 SAR data. International journal of applied earth observation and geoinformation, 73, 574-585.

Eskandari, H. and Attar, S., 2015. Energy comparison of two rice cultivation systems. Renewable and Sustainable Energy Reviews, 42, pp.666-671.

Esmaeilpour-Troujeni, M., Rohani, A. and Khojastehpour, M., 2021. Optimization of rapeseed production using exergy analysis methodology. Sustainable Energy Technologies and Assessments, 43, p.100959.

Esmaeilpour-Troujeni, M., Rohani, A., Khojastehpour, M., 2020. Application of Cumulative Exergy Consumption Approach to Assess the Sustainability of Rapeseed Production in Two Different Farming Systems. International Journal of Exergy, 33(4), 345-357.

Eusufzai, M.K., Tokida, T., Okada, M., Sugiyama, S.I., Liu, G.C., Nakajima, M. and Sameshima, R., 2010. Methane emission from rice fields as affected by land use change. Agriculture, ecosystems \& environment, 139(4), pp.742-748.

Firouzi, S., Nikkhah, A. and Aminpanah, H., 2018. Rice single cropping or ratooning agro-system: which one is more environment-friendly?. Environmental Science and Pollution Research, 25(32), pp.32246-32256. 
Fusi A., Bacenetti J., González-García S., Vercesi A., Bocchi S., Fiala M. (2014). Environmental profile of paddy rice cultivation with different straw management. Science of the Total Environment, 494-495, pp. 119-128.

Fusi, A., González-García, S., Moreira, M. T., Fiala, M., Bacenetti, J. (2017). Rice fertilised with urban sewage sludge and possible mitigation strategies: an environmental assessment. Journal of Cleaner Production, 140, 914-923.

Graziano, S., Marmiroli, N. and Gullì, M., 2020. Proteomic analysis of reserve proteins in commercial rice cultivars. Food Science \& Nutrition, 8(4), pp.1788-1797.

Habibi, E., Niknejad, Y., Fallah, H., Dastan, S. and Tari, D.B., 2019. Life cycle assessment of rice production systems in different paddy field size levels in north of Iran. Environmental monitoring and assessment, 191(4), pp.1-23.

Hepbasli, A. (2008). A key review on exergetic analysis and assessment of renewable energy resources for a sustainable future. Renewable and sustainable energy reviews, 12(3), 593-661.

Hoang, V.N. and Rao, D.P., 2010. Measuring and decomposing sustainable efficiency in agricultural production: A cumulative exergy balance approach. Ecological economics, 69(9), 1765-1776.

Jawad, H., Jaber, M.Y. and Nuwayhid, R.Y., 2018. Improving supply chain sustainability using exergy analysis. European Journal of Operational Research, 269(1), 258-271.

Juárez-Hernández, S., Usón, S. and Pardo, C.S., 2019. Assessing maize production systems in Mexico from an energy, exergy, and greenhouse-gas emissions perspective. Energy, 170, pp.199-211.

Khoshnevisan, B., Bashir, M.A., Sun, Q., Pan, J., Wang, H., Xu, Y., Duan, N. and Liu, H., 2021. Optimal rice-crab co-culture system as a new paradigm to air-water-food nexus sustainability. Journal of Cleaner Production, p.125936.

Lee, E.K., Zhang, W.J., Zhang, X., Adler, P.R., Lin, S., Feingold, B.J., Khwaja, H.A. and Romeiko, X.X., 2020. Projecting life-cycle environmental impacts of corn production in the US Midwest under future climate scenarios using a machine learning approach. Science of The Total Environment, 714, p.136697.

Lovarelli, D., \& Bacenetti, J. (2017). Bridging the gap between reliable data collection and the environmental impact for mechanised field operations. Biosystems engineering, 160, 109-123.

Masuda, K., 2018. Energy efficiency of intensive rice production in Japan: an application of data envelopment analysis. Sustainability, 10(1), p.120.

Maurya, B., Singh, P., Verma, O. and Mandal, D., 2017. Associations study of salt affected rice (Oryza sativa L.). J. Pharmacogn. Phytochem, 6, pp.843-847.

McFadden, B.R., Nalley, L.L. and Popp, M.P., 2013. How greenhouse gas emission policy and industry pressure could affect producer selection of rice cultivars. Agricultural and Resource Economics Review, 42(1203-2016-95508), 325-348.

Nabavi-Pelesaraei, A., Rafiee, S., Hosseini-Fashami, F. and Chau, K.W., 2021. Artificial neural networks and adaptive neuro-fuzzy inference system in energy modeling of agricultural products. In Predictive Modelling for Energy Management and Power Systems Engineering (pp. 299-334). Elsevier. 
Özilgen, M. 2018. Nutrition and production related energies and exergies of foods. Renewable and Sustainable Energy Reviews, 96, 275-295.

Özilgen, M. and Sorgüven, E., 2011. Energy and exergy utilization, and carbon dioxide emission in vegetable oil production. Energy, 36(10), pp.5954-5967.

Özilgen, M., \& Oner, E. S. 2016. Biothermodynamics: Principles and Applications. CRC Press.

Pelvan, E., \& Özilgen, M. (2017). Assessment of energy and exergy efficiencies and renewability of black tea, instant tea and ice tea production and waste valorization processes. Sustainable Production and Consumption, 12, 59-77.

Phitsuwan, P. and Ratanakhanokchai, K., 2014. Can we create "Elite Rice" - a multifunctional crop for food, feed, and bioenergy production?. Sustainable Chemical Processes, 2(1), p.10.

Pimentel, D. (1991). Ethanol fuels: Energy security, economics, and the environment. Journal of agricultural and environmental ethics, 4(1), 1-13.

Pingali, P.L. and Roger, P.A. eds., 2012. Impact of pesticides on farmer health and the rice environment (Vol. 7). Springer Science \& Business Media.

Rao, K.R., Gangwar, S., Bajpai, A., Chourasia, L. and Soni, K., 2018. Energy assessment of rice under conventional and drip irrigation systems. In Water Resources Management (pp. 19-29). Springer, Singapore.

Regione Lombardia, 2020. Disciplinari di produzione integrata. Comunicato regionale 7 aprile 2020 -

n.

(https://www.regione.lombardia.it/wps/portal/istituzionale/HP/DettaglioRedazionale/servizi-einformazioni/Imprese/Imprese-agricole/servizio-fitosanitario-regionale/uso-sostenibile-deiprodotti-fitosanitari/disciplinari-produzione-integrata/disciplinari-produzione-integrata.2020).

Regione Piemonte, 2020. Norme tecniche di produzione integrata, difesa, diserbo e pratiche agronomiche. Determinazione dirigenziale n. 159 del 01/04/2020 (http://www.confagricolturalessandria.it/documenti/tecnica/NormeTecniche-di-ProduzioneIntegrata-2020-DD-159-del-4apr2020.pdf)

Rocchi, L., Paolotti, L., Cortina, C. and Fagioli, F.F., 2020, October. An application of material circularity indicator to agricultural system. In Green metamorphoses: agriculture, food, ecology: Proceedings of the LV Conference of SIDEA Studies (pp. 95-101). Wageningen Academic Publishers.

Rosen, M. A., \& Dincer, I. (2001). Exergy as the confluence of energy, environment and sustainable development. Exergy, an International journal, 1(1), 3-13.

Shang, Q., Yang, X., Gao, C., Wu, P., Liu, J., Xu, Y., Shen, Q., Zou, J. and Guo, S., 2011. Net annual global warming potential and greenhouse gas intensity in Chinese double rice-cropping systems: a 3-year field measurement in long-term fertilizer experiments. Global Change Biology, 17(6), pp.2196-2210.

Szargut, J., \& Morris, D. R. (1987). Cumulative exergy consumption and cumulative degree of perfection of chemical processes. International journal of energy research, 11(2), 245-261. 
Szargut, J., Morris, D. R., \& Steward, F. R. (1988). Exergy analysis of thermal, chemical and metallurgical processes, Hemisphere Publ. Corp., New York, 331.

Taheri-Rad, A., Khojastehpour, M., Rohani, A., Khoramdel, S. and Nikkhah, A., 2017. Energy flow modeling and predicting the yield of Iranian paddy cultivars using artificial neural networks. Energy, 135, pp.405-412.

Taki, M., \& Yildizhan, H. (2018). Evaluation the sustainable energy applications for fruit and vegetable productions processes; case study: Greenhouse cucumber production. Journal of cleaner production, 199, 164-172.

Wall, G. (2003) 'Exergy tools’, Proc. Inst. Mech. Eng., pp.125-136.

Wittmus, H., Olson, L., \& Lane, D. (1975). Energy requirements for conventional versus minimum tillage. Journal of Soil and Water Conservation, 30(2), 72-75.

Xiao, C., Liao, Q., Fu, Q., Huang, Y., Xia, A., Shen, W., Chen, H. and Zhu, X., 2019. Exergy analyses of biogas production from microalgae biomass via anaerobic digestion. Bioresource technology, 289, p. 121709.

Yadav, R.B., Malik, S. and Yadav, B.S., 2016. Physicochemical, pasting, cooking and textural quality characteristics of some basmati and non-basmati rice varieties grown in India. International Journal of Agricultural Technology, 12(4), pp.675-692.

Yang, M., Xiao, W., Zhao, Y., Li, X., Huang, Y., Lu, F., Hou, B. and Li, B., 2018. Assessment of potential climate change effects on the rice yield and water footprint in the Nanliujiang catchment, China. Sustainability, 10(2), p.242.

Yildizhan, H. and Taki, M., 2018. Assessment of tomato production process by cumulative exergy consumption approach in greenhouse and open field conditions: Case study of Turkey. Energy, 156, pp.401-408.

Yildizhan, H. and Taki, M., 2019. Sustainable management and conservation of resources for different wheat production processes; cumulative exergy consumption approach. International Journal of Exergy, 28(4), pp.404-422.

Yildizhan, H., 2018. Energy, exergy utilization and CO2 emission of strawberry production in greenhouse and open field. Energy, 143, pp.417-423.

Yildizhan, H., Taki, M., Özilgen, M. and Gorjian, S., 2021. Renewable energy utilization in apple production process: A thermodynamic approach. Sustainable Energy Technologies and Assessments, 43, p.100956.

Yin, G., Liu, L. and Yuan, C., 2015. Assessing environmental risks for high intensity agriculture using the material flow analysis method - a case study of the Dongting Lake basin in South Central China. Environmental monitoring and assessment, 187(7), 1-17.

Zhang, B., Jin, P., Qiao, H., Hayat, T., Alsaedi, A. and Ahmad, B., 2019. Exergy analysis of Chinese agriculture. Ecological Indicators, 105, pp.279-291.

Zhang, B., Tian, H., Ren, W., Tao, B., Lu, C., Yang, J., Banger, K. and Pan, S., 2016. Methane emissions from global rice fields: Magnitude, spatiotemporal patterns, and environmental controls. Global Biogeochemical Cycles, 30(9), 1246-1263. 


\section{Appendix A}

Coefficients for calculation of energy consumption and cumulative exergy consumption in rice production (Yildizhan et al., 2020; Nabavi-Pelesaraei et al., 2021)

\begin{tabular}{lll}
\hline Inputs (unit) & Energy coefficient & $\begin{array}{l}\text { Cumulative exergy } \\
\text { (CExC) coefficient }\end{array}$ \\
\hline $\begin{array}{l}\text { 1.Diesel fuel } \\
\text { 2.Gasoline }\end{array}$ & $57.5 \mathrm{MJ} \mathrm{kg}^{-1}$ & $53.2 \mathrm{MJ} \mathrm{kg}^{-1}$ \\
3.Pesticides & $46.3 \mathrm{MJ} \mathrm{kg}^{-1}$ & $35.6 \mathrm{MJ} \mathrm{kg}^{-1}$ \\
$\quad$ & \\
(a) Herbicides & $198.8 \mathrm{MJ} \mathrm{kg}^{-1}$ & $32.7 \mathrm{MJ} \mathrm{kg}^{-1}$ \\
$\quad$ (b) Pesticides & $198.8 \mathrm{MJ} \mathrm{kg}^{-1}$ & $7.52 \mathrm{MJ} \mathrm{kg}^{-1}$ \\
(c) Fungicides & $198.8 \mathrm{MJ} \mathrm{kg}^{-1}$ & $4.56 \mathrm{MJ} \mathrm{kg}^{-1}$ \\
4.Fertilizers & & \\
(a) Nitrogen & $78.2 \mathrm{MJ} \mathrm{kg}^{-1}$ & $32.7 \mathrm{MJ} \mathrm{kg}^{-1}$ \\
(b) Phosphate $\left(\mathrm{P}_{2} \mathrm{O}_{5}\right)$ & $17.5 \mathrm{MJ} \mathrm{kg}^{-1}$ & $7.52 \mathrm{MJ} \mathrm{kg}^{-1}$ \\
(c) Potassium $\left(\mathrm{K}_{2} \mathrm{O}\right)$ & $13.8 \mathrm{MJ} \mathrm{kg}^{-1}$ & $4.56 \mathrm{MJ} \mathrm{kg}^{-1}$ \\
5. Farmyard manure & $0.35 \mathrm{MJ} \mathrm{kg}^{-1}$ & $5.33 \mathrm{MJ} \mathrm{kg}^{-1}$ \\
\hline
\end{tabular}

